\title{
Technical evaluation of serological screening tests for anti-Toxoplasma gondii antibodies to prevent unnecessary transfusion risks
}

\author{
Avaliação técnica de testes de triagem sorológica para detecção de anticorpos anti-Toxoplasma \\ gondii como medida preventiva a riscos transfusionais desnecessários
}

Rogério $S . \mathrm{Vaz}^{1}$

Ana T. B. Guimarães ${ }^{2}$

Larissa D. Bonanato ${ }^{3}$

Vanete Thomaz-Soccol ${ }^{4}$
Serological assays to detect anti-Toxoplasma gondii antibodies and specific anamnesis associated with this highly prevalent infection could be necessary in hemotherapy services in order to regulate safer blood supplies thus avoiding unnecessary transfusion risks. Even though, such policies are not yet implemented. In order to evaluate this requirement, our research group designed a questionnaire filled up by 132 volunteer blood donors from Parana Hemotherapy Center (Hemepar) assessing the possible risk factors to toxoplasmic infection. A total of $20 \mathrm{IgG}$ anti-Toxoplasma serological tests were done to check out for positive-reactivity. $60 \%$ of the selected serum samples reacted positively; from these, 50\% reported having pets (average of 2 animals per person) and 33\% of these pets were "semi-free". It suggested the probability of toxoplasmic infection through these animals. Only 2.2\% of the interviewed individuals were aware of the correct concept of the disease and only $17 \%$ of them were actually approached by the Blood Center concerning the epidemiological importance of this disease. The current procedures established during blood transfusions are not entirely safe when associated to toxoplasmosis. Today there are no rules that standardize a seroscreening protocol, nor preventive measures for this disease related to hemotherapy services in Brazil, as well as in other services worldwide. Rev. bras. hematol. hemoter. 2008;30(4):277-280.

Key words: Toxoplasmosis; blood banks; IgG anti-Toxoplasma gondii.

\section{Introduction}

Toxoplasmosis is a zoonose caused by Toxoplasma gondii that shows a high prevalence worldwide. ${ }^{1}$ In the USA and UK, the estimated prevalence is $16-40 \%$, being great part of this population with chronicle and/or asymptomatic forms of this disease. ${ }^{2}$

This prevalence can be related to age, while the majority of the cases of acute clinical forms can be related with the ingestion of raw, cured or undercooked meat. ${ }^{3,4}$ The seroprevalence can be associated to multifactors like: environment, alimentary habits, cultural factors. ${ }^{5}$

For the diagnosis of toxoplasmosis, although not mandatory, blood bank services use automatized or manual imunoenzimatic methods for the evaluation of the presence of circulating $\operatorname{IgM}$ and IgG antibodies in serum and/or plasma samples. ${ }^{6}$ However, great part of the toxoplasmosis cases are presented in chronic phase and seldomly symptomatic.

Blood donors in serological window and/or in parasitemia are mostly asymptomatic, thus representing a serious problem to safe blood supply, since the infectant

${ }^{I}$ Researcher - IESPP - Instituto de Ensino Superior Pequeno Príncipe \& Instituto de Pesquisa Pelé Pequeno Príncipe, Post-doctoral Researcher

- Molecular Parasitology Laboratory - Universidade Federal do Paraná.

${ }^{2}$ Professor of Parasitology - Faculty of Biological Sciences, Universidade Positivo - Curitiba-PR.

${ }^{3}$ Faculty of Biological Sciences, Universidade Positivo - Curitiba-PR.

${ }^{4}$ Head of the Molecular Parasitology Laboratory - Basic Pathology Department - Universidade Federal do Paraná.

Correspondence: Rogério Saad Vaz

Instituto de Pesquisa Pelé Pequeno Príncipe

Av. Silva Jardim, $n^{\circ} 1632$

ZIP Code 80230-020 - Curitiba-PR - Brazil

Phone: 55 41-33101035

E-mail:rogeriovaz@fpp.edu.br 
forms of $T$. gondii can remain viable in hemocomponents conditioned in temperature of refrigeration $\left(2^{\circ} \mathrm{C}-8^{\circ} \mathrm{C}\right)$ and with chemical preservatives (CPDA-1) for more than 90 days.

The hypothesis raised in this study is that the seroprevalence of $T$. gondii is highly underestimated by the great majority of hemotherapy services, once there are no anamnestic procedures related to this parasitc infection.

Serological screening procedures for toxoplasmosis in brazilian or international blood banks is not mandatory. ${ }^{7}$ The present study aimed to evaluate the necessity of technical implantation of serological immunoassays for the detection of anti-T. gondii antibodies in hemotherapy and hematology public services of the State of the Paraná - South of Brazil (Hemepar).

\section{Material and Method}

This study was carried out at the Hematology and Hemotherapy Center of Parana State (Hemepar-Curitiba). This project was approved in April 2005, and it was in accordance to the rules of the Research and Ethics \& Scientific Initiation Committee of the Universidade Positivo (UP - CEP/04-2005). The questionnaires used to evaluate the volunteer blood donors at Hemepar were also in accordance to UP-CEP and the Hemepar clinical board. Both committees established that all blood donors should previously fill up a "Term of Informed and Free Consent" in order to participate in this study, and the names of the participants were guaranteed to remain anonymous. 132 volunteer blood donators accepted to participate in this

Table 1. Socio-demographic and risk factors data questionnaire applied to the selected blood donors

\begin{tabular}{|c|c|c|}
\hline Categories & Related Question(s)/Information & Related Answer(s)/Information \\
\hline & $\begin{array}{l}\text { a) Blood Drawing Date } \\
\text { b) Hemotherapy Service Registration Number }\end{array}$ & \\
\hline \multirow{5}{*}{$\begin{array}{l}\text { I - Blood Donors } \\
\text { Demographic Data }\end{array}$} & c) Name /Code & - Name (Initials); Bar Code \\
\hline & d) Sex & - M - Male; F - Female \\
\hline & & $\begin{array}{l}\text { - City; State; Country } \\
\text { - Kilograms (Kg) }\end{array}$ \\
\hline & h) Literacy & $\begin{array}{l}\text { - Elementary / Middle School (Complete or Incomplete) } \\
\text { - High School (Complete / Incomplete; - Intermediate } \\
\text { (Technical degree (Complete / Incomplete); - Higher } \\
\text { Degree (Complete / Incomplete); - Post-graduation } \\
\text { (Complete / Incomplete) }\end{array}$ \\
\hline & a) What is the reason of the Blood Donation? & $\begin{array}{l}\text { - Altruistic; Recipient Oriented } \\
\text { - Family Case (Designated Donation) } \\
\text { - Phenotyping; Other(s) }\end{array}$ \\
\hline $\begin{array}{l}\text { II - Blood Donor } \\
\text { Characterization }\end{array}$ & $\begin{array}{l}\text { b) Have you ever had blood donated before? } \\
\text { If, the answer is YES, please indicate how } \\
\text { many pets you do own: }\end{array}$ & - Yes; - No \\
\hline \multirow[t]{10}{*}{ Risk factors } & $\begin{array}{l}\text { c) Food Intake habits/preferences: } \\
\text { Do you eat raw / undercooked or cured meat? }\end{array}$ & - Yes; - No \\
\hline & $\begin{array}{l}\text { d) In the above question, if you indicated YES, } \\
\text { please specify how many times a week you do } \\
\text { eat one or more of the above indications. }\end{array}$ & \\
\hline & $\begin{array}{l}\text { e) Do you own a Pet? } \\
\text { If, the answer is YES, please indicate } \\
\text { how many pets you do own }\end{array}$ & -Yes; - No \\
\hline & f) Please specify what Pet(s) specie(s) you own & $\begin{array}{l}\text { dog, cat, bird, turtle, hamster/other or other small rodent, } \\
\text { Other(s) - indicate: }\end{array}$ \\
\hline & $\begin{array}{l}\text { g) Person in charge of cleaning the pet(s) } \\
\text { physiological disposals? }\end{array}$ & $\begin{array}{l}\text { - yourself, your parent(s), sibling(s), employee(s), other(s) - } \\
\text { specify: }\end{array}$ \\
\hline & $\begin{array}{l}\text { h) How do you manage the cleaning procedures? } \\
\text { Indicate briefly: }\end{array}$ & \\
\hline & i) Please indicate your pet(s) life style & Indoor, Outdoor, Semi-free (in and outdoor). Specify: \\
\hline & j) What kind of food do you offer to your pet(s)? & $\begin{array}{l}\text { industrialized pet food, food leftovers, raw food/meat } \\
\text { Other source? If so, indicate: }\end{array}$ \\
\hline & $\begin{array}{l}\text { I) Do you have any previous toxoplasmosis clinical } \\
\text { family history? }\end{array}$ & $\begin{array}{l}- \text { Yes; - No; } \\
\text {. Not known }\end{array}$ \\
\hline & $\begin{array}{l}\text { m) During your interview at the blood bank, } \\
\text { previously to blood donation, the interviewer } \\
\text { asked any question concerning "Toxoplasmosis" } \\
\text { or any other relate question? }\end{array}$ & - Yes; - No \\
\hline
\end{tabular}


study by answering to a list of opened and closed questions, Table 1.

Donors of both sexes had been selected randomly and they were included with the characteristics defined through national policies of Blood Banks. ${ }^{8}$

The application of the questionnaire occurred after the donation and it was promoted by the blood bank staff and the research group. Twenty blood samples of voluntary donors were drawn, and stored, in a random fashion in vacutainer tubes with EDTA (Vacuntainer System -Becton \& Dickinson $\left.{ }^{\circledR}\right)$.

The blood samples were processed at the Universidade Positivo (UP), where they were submitted to serologic immunoassay (ELISA- Katal Biotecnológica Ind. \& Com. Ltda) for determination of anti-Toxoplasma gondii antibodies - IgG $(\lambda=450 \mathrm{~nm})$. The linear regression $\left(\mathrm{r}^{2}\right)$ between age and IgG serum absorbances values was calculated.

\section{Results}

\section{Socio-demographic variables}

Age and weight (values are shown as means) and frequencies of socio-demographic variables. The sample shows a higher number of female donors $(62,88 \%)$, and a direct association between educational level of primary and secondary school. $59,1 \%$ of interviewed declared that the aim of the donation was altruistic (Table 2).

\begin{tabular}{|c|c|c|}
\hline Variables & Categories & $\begin{array}{l}x \pm \sigma / \\
\text { Frequence }\end{array}$ \\
\hline $\mathrm{Age}^{\mathrm{a}}$ & $\begin{array}{l}\text { Male } \\
\text { Female }\end{array}$ & $\begin{array}{l}34 \pm 10,1 \\
30 \pm 10,7\end{array}$ \\
\hline Weight $^{b}$ & $\begin{array}{l}\text { Male } \\
\text { Female }\end{array}$ & $\begin{array}{l}78,10 \pm 11,9 \\
64,38 \pm 10,3\end{array}$ \\
\hline Sex ${ }^{a}$ & $\begin{array}{l}\text { Male } \\
\text { Female }\end{array}$ & $\begin{array}{l}37,12 \\
62,88\end{array}$ \\
\hline \multirow[t]{8}{*}{ Level of Literacy ${ }^{a}$} & $\begin{array}{l}\text { Elementary School / } \\
\text { Middle School (Incomplete) }\end{array}$ & 3,03 \\
\hline & $\begin{array}{l}\text { Elementary School / } \\
\text { Middle School (Complete) }\end{array}$ & 13,64 \\
\hline & High-school (Incomplete) & 5,30 \\
\hline & High-school (Complete) & 40,91 \\
\hline & Higher Degree (Incomplete) & 18,18 \\
\hline & Higher Degree (Complete) & 11,36 \\
\hline & Technologist (Intermediate) & 3,79 \\
\hline & Post-graduation & 3,79 \\
\hline \multirow{5}{*}{$\begin{array}{l}\text { Reasons to } \\
\text { Donate Blooda }\end{array}$} & Altruistic & 59,10 \\
\hline & Recipient - Specific & 34,11 \\
\hline & $\begin{array}{l}\text { Familiy Case } \\
\text { (Designated Donation) }\end{array}$ & 8,35 \\
\hline & Pheotyping & 2,28 \\
\hline & Others & 1,52 \\
\hline
\end{tabular}

Statistical analysis

$51 \%$ of the interviewed donors declared to have domestic animals. $45 \%$ of these animals had semi-free behavior and $13 \%$ were fed with remaining food portions of family meals, or with raw meat. Another alarming data showed that only $2.2 \%$ of the sampling demonstrated knowledge of the correct concept of toxoplasmosis. Moreover, only $17 \%$ of the donors were informed by the blood bank concerning the epidemiological importance of the T. gondii infection.

Such results could indicate that the procedures established previous and after blood transfusions may not assure the prevention of the toxoplasmosis nor avoid associated transfusion risks. Part of the interviewed donors $(33 \%)$ declared to eat raw and/or partially cooked meat at least once a week, increasing contamination risks.

The serologic analysis of the donors evidenced that $60 \%$ were seroreactive. $25 \%$ had the habit to eat raw meat in average 1 time per week and 50\% had domestic animals (average of 2 animals per person). $33.3 \%$ of these animals had semi-free behavior. $67 \%$ of the seroreactive donors that had domestic animals declared to be the ones to clean up the physiological disposals of such animals, thus increasing risks of contamination to them.

A statistical significance relation was obtained $(\mathrm{r} 2=$ $0,2613 ; \mathrm{t}=2,1 ; \mathrm{GL}=17)$, where $26 \%$ of the variance of the data can be explained by a plotted straight line shown below in a graphic - Figure 1.

Probably with a broader number of samples (n), this relation could be more significant. After the accomplishment of the analysis, the samples with high reactivity indicated a possible relation between the seroprevalence and the presence of domestic animals in the domiciles.

\section{Conclusions}

The seroprevalence of $60 \%$ of anti-Toxoplasma gondii immunoglobulines $(\operatorname{IgG})$ is in accordance with data from other

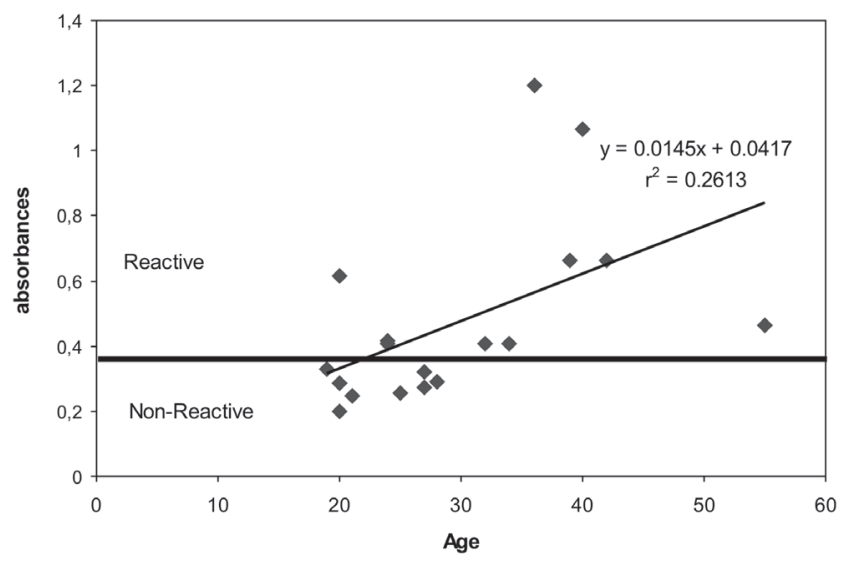

Figure 1. Linear regression between age (from blood donors) and the specrophotometric absorbances values of IgG anti-Toxoplasma gondii 
researchers in different regions of the world. Seroprevalence values oscillate between $20 \%$ to $90 \%{ }^{9}$

In our study, the population presented a higher probability of contamination from animals, mainly cats, who are the definitive hosts of this parasite. One of the main ways of contamination occurs during manual cleaning of excrements from animals, ${ }^{10}$ being, therefore a suggestion of the transmission form that could be occurring in the investigated individuals.

As 33\% of the interviewed had the habit to eat raw meats in average 1 time per week, thus suggesting a strong relationship with higher risks of contamination, as demonstrated by Bonametti et al. ${ }^{11}$ This prevalence indicates that transfusion contamination risks are high, since, currently, there are no legislation, nor technical policies demanding seroscreening protocols for toxoplasmosis.

This scenery occurs not only in Brazil, ${ }^{7}$ but also in many other countries throughout the globe. ${ }^{12}$ Specific anamnesis previous to blood drawing and systematic seroscreening for anti-Toxoplasma gondii antibodies should be implemented to assure safe blood components, specially to immunocompromised patients. ${ }^{13}$

The data shown in this study also suggests obligatoriness of Hemotherapy Services to clarify the epidemiological importance of this parasitic disease to blood donning population, as well to blood component recipients and to adopt prophylactic procedures, as a measure to guarantee a safe blood supply and consequently too avoid unnecessary transfusion risks.

\section{Resumo}

A avaliação da necessidade técnica de implantação de teste sorológico para a detecção de anticorpos anti-Toxoplasma gondii em rotina de serviços de hemoterapia e de uma anamnese com questões ligadas ao ciclo de infecção por Toxoplasma gondii foi feita a partir da aplicação de 132 questionários ao público doador do Centro de Hematologia e Hemoterapia do Paraná (Hemepar) para avaliação dos possiveis fatores de risco ao contágio da toxoplasmose e de 20 testes sorológicos para análise de reatividade positiva a IgG anti-Toxoplasma gondii. Das amostras analisadas sorologicamente, $60 \%$ obtiveram reatividade positiva. Destes, $50 \%$ possuíam animais domésticos (média de dois animais por pessoa), dos quais 33\% dos animais possuia vida semilivre. Após análise das amostras, foi aplicado um estudo de coorte para a formação de um grupo de doadores passiveis de infecção por Toxoplasma gondii e um grupo de não passíveis de infecção, o que não mostrou uma tendência significativa relacionada a fatores de risco. Tal cenário sugere a probabilidade de contágio a partir de animais, porém apenas 2,2\% da amostragem conhecia o conceito correto sobre a doença e somente $17 \%$ dos doadores foram abordados pelo banco de sangue sobre a importância epidemiológica do parasito. Tais resultados levam a crer que os procedimentos estabelecidos durante as transfusões sangüineas não se mostram tão seguros, possibilitando o contágio durante uma transfusão. Atualmente, não há nenhuma legislação que estabeleça um protocolo de diagnóstico para esta doença. Este cenário ocorre tanto no Brasil quanto em outros países, não existindo, portanto, a obrigatoriedade da realização dos testes de triagem sorológica para Toxoplasmose por parte dos bancos de sangue.Rev. bras. hematol. hemoter. 2008; 30(4):277-280.

Palavras-chave: Toxoplasmose; bancos de sangue; IgG antitoxoplasma.

\section{Acknowledgments}

We would like to thank to all clinical, technical personnel and the directive board of Hemepar to support this research throughout the year of 2005. This research project was financially supported by the Scientific Committee of the Universidade Positivo, and also had technical support from the Molecular Parasitology Laboratory from the Universidade Federal do Parana-Curitiba-PR-Brazil.

\section{References}

1. Rey LC, Ramalho ILC. Soroprevalência da toxoplasmose em Fortaleza, Ceará, Brasil. Rev Inst Med Trop S Paulo. 1999;41(3):171-4.

2. Hill D, Dubey JP. Toxoplasma gondii: transmission, diagnosis and prevention. Clin Microbiol Infect. 2002;8(10):634-40.

3. Garcia JL, Navarro IT, Ogawa L. Soroepidemiologia da toxoplasmose e avaliação ocular pela Tela de Amsler, em pacientes da zona rural, atendidos na unidade de saúde do município de Jaguapitã, PR, Brasil. Rev Soc.Bras Med Trop. 1999;32(6):671-6.

4. Nimri L, Pelloux H, Elkhatib L. Detection of Toxoplasma gondii DNA and specific antibodies in high-risk pregnant women. Am J Trop Med Hyg. 2004;71(6):831-5.

5. Spalding SM, Amendoeira MR, Klein CH, Ribeiro LC. Serological screening and toxoplasmosis exposure factors among pregnant women in South of Brazil. Rev Soc Bras Med Trop. 2005;38(2):173-7.

6. Wendel S. Current concepts on transmission of bacteria and parasites by blood components. Vox Sang. 1994;67 Suppl 3:161-74.

7. Carazzone CFV, Brito AM, Gomes YM. Importância da avaliação sorológica pré-transfusional em receptores de sangue. Rev Bras Hematol Hemoterap. 2004;26(2):93-8.

8. Agência Nacional de Vigilância Sanitária (Anvisa). Sangue e hemoderivados. Manuais e publicações. (www.anvisa.gov.br/sangue/legis/ index.htm) [capturado em 08/05/2008].

9. Cantos GA, Prando MD, Siqueira M. Toxoplasmose: ocorrência de anticorpos anti-Toxoplasma gondii e diagnóstico. Rev Assoc Med Bras. 2000;46(4):335-41.

10. Langoni H, Silva AV, Cabral KG. Prevalência de toxoplasmose em gatos dos Estados de São Paulo e Paraná. Braz J Vet Res Anim Sci. 2001;38(5):243-4.

11. Bonametti AM, Passo JN, Silva EMK. Surto de toxoplasmose aguda transmitida através da ingestão de carne crua de gado ovino. Rev Soc Bras Med Trop. 1997;30(1):21-5.

12. Pinlaor S, Ieamviteevanich K, Pinlaor P, Maleewong W, Pipitgool V. Seroprevalence of specific total immunoglobulin (Ig), IgG and IgM antibodies to Toxoplasma gondii in blood donors from Loei Province, Northeast Thailand. Southeast Asian J Trop Med Public Health. 2000;31(1):123-7.

13. Walker M, Zunt JR. Parasitic central nervous system infections in immunocompromised hosts. Clin Infect Dis. 2005;40(7):1005-15.

Avaliação: Editor e dois revisores externos

Conflito de interesse: não declarado

Recebido: $15 / 06 / 2007$

Aceito: 22/05/2008 